\title{
Waste management legislation in Russia and China: a comparative aspect
}

\author{
Tatiana Ivanova $^{1}$ and Cuiyi $\mathrm{Wu}^{2}$ \\ ${ }^{1}$ North-Eastern Federal University, Faculty of Law, 677000 Yakutsk, Yakutia \\ ${ }^{2}$ University of Versailles Saint-Quentin-en-Yvelines, Faculty of Law and Political Science, 78280 Guyancourt, France
}

\begin{abstract}
The purpose of this article is to review Russian and Chinese waste legislation. Although there are political and institutional differences between the two countries, they converge with each other in terms of internationalization, regionalization trends, geographic relations, customs and habits. In addition, international cooperation has been established between China and Russia in the field of solid waste disposal; therefore it is very important to study the rules at the international level regarding the import and export of solid waste, as well as the disposal of waste hazardous to human health and the environment.
\end{abstract}

\section{Introduction}

Industrialization caused by scientific and technological progress destroys natural spaces, pollutes the environment and threatens human health. After a significant number of environmental disasters in the world, environmental movements are becoming more active. The diversity of pollution sources has led to a de facto sectoral approach in international environmental law.

As you know, waste is everything that is no longer useful for us and that we decide to throw it away, and its rapid increase, in addition to industrialization, is also caused by population growth and an increase in people's living standards.

Currently, the waste that has become a companion of people with whom they live in everyday life cannot be processed in time, which leads not only to the pollution of useful spaces for them, but also to very high costs due to the lack of effective management. It is within this framework that the fight against environmental pollution with waste is carried out at the international level.

Russia, as a neighbor and partner of China, is also interested in the implementation of joint measures and environmental protection measures at the interstate level. Both states are parties to international treaties: Basel Convention on the Control of Transboundary Movements of Hazardous Wastes and Their Disposal (1989),
Stockholm Convention on Persistent Organic Pollutants (POPs) (2007), Convention on the Prevention of Marine Pollution by Dumping of Wastes and Other Matter [1].

With rapid economic growth and strong domestic demand, Russia and China face a particular waste management challenge. And most of the waste in these two countries is not recycled, but piled up in landfills, polluting the soil.

In Russia, according to Rosprirodnadzor, more than 3 billion tons of industrial waste, more than 40 million tons of municipal solid waste, 80-100 million tons of waste water from industrial and municipal enterprises, hundreds of millions of tons of pig and poultry manure, as well as tens of million tons of construction waste [2]. Thus, despite the fact that these various wastes should be used as a secondary resource in various industries in accordance with the national project «Ecology», $90 \%$ of municipal solid waste is sent to landfills and only $7 \%$ is recycled. This conclusion was reached by the auditors of the Accounts Chamber [3]. Thus, we have to admit that the garbage reform in Russia has failed.

However, the rate of recycling of various types of waste varies significantly depending on the resource value of the waste, the nature of its environmental pollution and specific economic conditions. Economic conditions also affect the rate of waste disposal. Indeed, according to 
official data, about $50 \%$ of generated waste is accumulated in Russia every year, i.e. 3-3.4 billion tons [4]. In many cases, this is due to the high cost of recycling and processing waste, which makes it less profitable or completely unprofitable. Another reason is that the waste needs to be shredded and then processed into secondary materials or semi-finished products, and there are usually inclusions in the recycled waste, which leads to a decrease in the productivity of the waste processing plant.

In China, more than $90 \%$ of industrial waste is not recycled at all, and in recent years, billions of tons of waste generated at large industrial sites have accumulated in landfills and pollute soil and groundwater.

According to a professor at the Beijing Institute of Civil Engineering, Chen Jialong, «Most of the waste comes from construction sites and is illegally dumped around large cities, which pollutes the environment and causes serious problems. Like household waste, it has a negative impact on the environment. After the well-known package of measures to stimulate the Chinese economy in 2009 in the amount of more than 461 billion euros, we are beginning to see the opposite consequences» [5]. Most of them were spent on infrastructure projects. Bridges, roads, railways, housing estates and offices are mushrooming. Currently, 36 million social housing units, one hundred airports and thousands of kilometers of railways are under construction. Not to mention the two billion square meters of office and residential space that are commissioned every year. Excavators and cranes appeared everywhere. The country absorbs $40 \%$ of the world's cement and steel production. As a result, China has become the world's largest construction site.

However, nothing was planned for the recycling and treatment of the billions of tons of waste from these operations. In Beijing, of the 100 million tons of waste generated daily, $40 \%$ comes from construction sites. There is seven-time more waste than that in all Western countries. But only $5 \%$ of this waste is processed in accordance with legal requirements, and only $1 \%$ is recycled, because developers still do not want to entrust their waste to specialists for processing, as costs increase their bills. It is difficult for green companies to be profitable, so the bricks they produce from recycled waste are more expensive than conventional materials and the price is still not competitive enough.

\section{Results and Discussion}

After incidents of environmental pollution by waste, China and Russia have gradually realized the seriousness of the waste problem, and in order to change this situation and in order to protect the environment, Russia and China are reforming their national legislation on waste management.

For example, the Chinese parliament on April 29, 2021, adopted a law unprecedented in the world to combat wasteful use of food. If earlier the Chinese authorities were faced with the task of feeding the entire population of the country, now another problem has arisen. It has been estimated that about 35 million tons of food in China becomes waste every year before reaching consumers. According to the study, in large cities - Beijing, Shanghai, Chengdu and Lhasa, an average of 17-18 million tons of food is thrown away annually, which could feed 30-50 million people a year [6]. Under the threat of large fines, shops, restaurants, fast food outlets are switching to the prudent use of products. Other countries are expected to follow China's example as well.

From the point of view of comparative environmental law, there are relatively few comparative studies of waste management legislation between China and Russia [7, 8, 9, 10, 11].

The circle of questions that will guide our thinking is: Is there an effective waste management policy in Russia and China? If such a policy exists, what is the legal framework in both countries? Are the legal provisions of Russian and Chinese legislation applied in the same way or differently? Is waste management effective in both legislation? Is the waste these countries seem to be struggling with not a hazard?

China's legal system for waste management follows the traditional pyramid model, which is based on the Constitution and the Law of the People's Republic of China on the Prevention of Environmental Pollution by Solid Waste, including administrative regulations, local ordinances and environmental standards for waste [9].

As for Russia, the regulatory and legal framework for waste management is very complex and includes federal laws, decrees of the Russian Government, sanitary norms and rules, building codes, state standards, as well as norms and rules for handling hazardous waste. Of these, the most important is the Federal Law of June 24, 1998 No. 89-FZ «On production and consumption waste», which defines the goals and principles of waste management.

The study of the comparison of the legislation of both countries leads to the following conclusions. First, the classification of waste is 
the same in the two states. Second, the legislative goals of China and Russia are to protect human health and the environment, although for Russia its legislative goal is not directly indicated in the Federal Law of June 24, 1998, but is reflected in Article 3 of this law. Third, the principle of prevention and the concept of sustainable development are reflected in all Russian and Chinese legislation. Fourth, with regard to measures and means of supervision and waste management, Russia and China, both states, provide a variety of supervision measures for waste management. Finally, both countries have sanctions for non-compliance with waste legislation.

However, this comparison shows that the two legal systems are not identical in all aspects. First of all, with regard to the waste management system, China has not yet developed clear, detailed and operational provisions on the relationship between a single supervisory and management body - the Department of Environmental Protection and other competent waste disposal authorities. In Russia, the principle of delineation of powers is in force; this also applies to waste management. In addition, regarding the liability of waste generators, the Solid Waste Law in China is very detailed, including the liability of the administrative authorities, citizens and legal entities and, in general, criminal, administrative and civil liability. For Russia, on the contrary, federal law provides for administrative, criminal or civil liability, but the details of this liability are not specified in the law.

Despite the fact that the legislation of both countries provides for environmentally friendly waste management, there are some shortcomings. In the Russian model, this is in fact the limited responsibility of waste producers, ignoring the possibility of using waste as a secondary resource in the law (this is the absence of such concept in the law), shortcomings of the federal law in the field of waste management in terms of the effectiveness of supervision in the field of waste management. The Chinese model is characterized by low efficiency of the regulatory framework for waste management, duplication and contradiction of Chinese legislation, ambiguity of some waste management rules and shortcomings of legislation on waste classification.

\section{Conclusion}

As a result of a brief comparative analysis, we come to the following conclusions. Both Russia and China need to confirm the concept of a circular economy in waste management within the framework of legislative acts, to clarify the distribution of responsibilities. They need to improve the segregated waste collection system and the extended producer responsibility scheme. In addition, if China and Russia can strengthen international cooperation on waste management, it will help green economic development and save resources and energy in both countries.

\section{Acknowledgments}

This study was funded by the Russian Foundation for Basic Research (RFBR) in accordance with research project No. 21-510-22001 «State regulation of subsoil use and environmental protection in France and the Arctic zone of the Russian Federation: a comparative study, methodology and practice», conducted jointly by RFBR and Foundation «House of Human Sciences» of France".

\section{References}

1. E.I. Dmitrieva, Young scientist 11, 1782-1784 (2015)

2. URL:

https://rpn.gov.ru/activity/regulation/help/ (date of access: 09.09.2021)

3. URL:

https://www.gazeta.ru/business/2020/09/29/13 273099.shtml?updated (date of access: 09.09 .2021 )

4. URL: https://rpn.gov.ru/activity/regulation/help/ (date of access: 09.09.2021)

5. URL: https://www.terraeco.net/La-Chinecroule-sous-ses-dechets, $17753 . \mathrm{html}$ (date of access: 09.09.2021).

6. URL: $\quad$ https://ria.ru/20210429/eda1730422442.html (date of access: 09/08/2021)

7. X. Jing, T. Yingyan, G. Dongmei. Research and suggestions on the status of waste management and laws and regulations in Russia, Study on Regional and Country Environmental Protection of ACO, 16 (2016).

8. L.I. Jinhui, N. Yongfeng, B. Qingzhong Journal Techniques and Equipment for Environmental Pollution Control, (6), P. 12-22. 1998

9. E.Y. Kabysheva, Young scientist 10.3, 20-21 (2016)

10.W. Shuyi, L.I. Qiaoling, Health \& Environment J. S 11, 17-20 (2004) 
11.H. Sun, Journal of Hebei University 5, 506-514 (2006) 